\title{
Thornthwaite-Mather vandens balanso modelio taikymas Lietuvos upėms
}

\author{
Edvinas Stonevičius, \\ Dovydas Reitelaitis \\ Vilniaus universitetas, \\ M. K. Čiurlionio g. 21, \\ LT-03101 Vilnius \\ El.paštasedvinas.stonevicius@gf.vu.lt
}

Stonevičius E., Reitelaitis D. Thornthwaite-Mather vandens balanso modelio taikymas Lietuvos upèms. Geologija. Geografija. 2016. T. 2(3). ISSN 2351-7549.

Mènesio laiko žingsnio vandens balanso modeliai dažnai taikomi vertinant baseinų, kurių hidrologinių bei meteorologinių duomenų prieinamumas yra mažas, nuotèkị. Tokio tipo modeliai gali būti taikomi ir tada, kai sudètingesniems modeliams pritaikyti trūksta duomenų, leidžiančių apibūdinti modelyje vertinamus nuotèki formuojančius procesus. Šiame darbe Thornthwaite-Mather modeliu skaičiuotas penkių skirtingo maitinimo ir baseino savybių Lietuvos upių nuotèkis, siekta ịvertinti, kokios yra šio mẻnesio laiko žingsnio vandens balanso modelio stipriosios ir silpnosios savybės vertinant vidutinio dydžio upių nuotèkị, būdingą regionui.

Atlikta modeliu apskaičiuoto nuotèkio jautrumo modelio parametrų vertėms analizè. Tirtiesiems upių baseinams modelis taikytas Monte Karlo optimizavimo metodu nustatant geriausiai baseinuose vykstančius nuotèkio formavimosi procesus, atspindinčius modelio parametrų derinius. Su pasirinktais kiekvienos upés baseinui optimaliais parametrais modelis tiksliai gali ịvertinti vidutinę daugiametę sezoninę nuotèkio kaitą. Geriausiai modeliu atspindimi nuotekkio formavimosi procesai šaltuoju metų laiku ir per pavasario potvynius, o per vasaros nuosèkị ir rudens nuotèkị modelis tiksliai ịvertina ne visose upèse. Daugiametę nuotèkio kaitą ThornthwaiteMather modelis geriausiai apibūdina upèse, kurių sezoninè nuotèkio kaita yra didžiausia, o natūralus nuotèkio reguliavimas mažiausias. Modelis gali efektyviai įvertinti viso tirtojo laikotarpio spalio-balandžio mèn. nuotèki upèse su mažu natūraliu nuotèkio reguliavimu, o maža sezonine nuotèkio kaita pasižyminčių upių nuotèkį atspindi nepakankamai efektyviai.

Raktažodžiai: nuotekis, modeliavimas, Thornthwaite-Mather modelis, jautrumo tyrimas, Monte Karlo optimizavimo metodas

\section{IVADAS}

Modelis - supaprastinta tiriamosios sistemos realizacija. Remiantis modeliais galima įvertinti, kaip tiriamoji gamtinè sistema reaguos $i \mathfrak{i s ̌ o r i n i ~ p o v e i - ~}$ ki, pavyzdžiui, kaip ị upès baseiną iškritę krituliai transformuosis ị nuotekį. Kritulių transformacija i nuotèki vyks priklausomai nuo to, kokios yra baseino savybès. Tas pats efektyvių kritulių kiekis įvairaus dydžio, reljefo, žemėnaudos ir dirvožemio baseinuose lems skirtingą nuotèki. Norint modeliu imituoti visus baseine vykstančius procesus reikètų turèti išsamią ir didelès raiškos informaciją apie baseino savybes ir jų pasiskirstymą. Tokia informacija retai būna prieinama, todèl dauguma hidrologinių ir vandens balanso modelių yra konceptualūs arba iš dalies konceptualūs. Tokiuose modeliuose dažniausiai laikoma, kad baseino savybès nekinta didelèse teritorijose, pavyzdžiui, pabaseinyje arba net visame baseine, o procesai, 
lemiantys nuotèkio transformaciją, yra suprastinami. Paprastesnè modelio struktūra gali lemti didesni modelio rezultatų neapibrěžtumą, tačiau sumažèja neapibrèžtumas, atsirandantis dèl ne tiksliai apibūdinamų tiriamosios sistemos savybių. Bendras modelio neapibrèžtumas priklauso nuo tiriamosios sistemos pažinimo ir prieinamo duomenų kiekio, tad konceptualių ir fiziniais procesais paremtų modelių rezultatai ne retai būna panašaus tikslumo (Arnall, 1992; Xu, Singh, 1998; Poulin ir kt., 2011; Najafi ir kt., 2011).

Supaprastinant procesus, vykstančius baseine, modelio skaičiavimuose galima naudoti ilgesnius laiko žingsnius, tai lemia galimybę tyrimui panaudoti vidutinius paros, ménesio ar metų ìvesties duomenis. Nuo modelyje naudojamo laiko žingsnio priklauso, kokios laiko raiškos sistemos reakciją i išorès poveiki galèsime tirti. Jei naudosime metų laiko žingsni, galèsime įvertinti tik daugiametes vertes, o naudodami ménesio laiko žingsnio modelius galima ịvertinti ir sezoninę tiriamųjų elementų kaitą. Mènesio laiko žingsnio vandens balanso modeliai dažnai taikomi klimato poveikio tyrimams (Gleick, 1986, 1987; McCabe, Ayers, 1989; Boorman, Sefton, 1997; Jiang ir kt., 2007; Wang ir kt., 2013), nes tokio tipo modeliams pakanka kelių klimato įvesties duomenų, o didelis klimato kaitos projekcijų neapibrèžtumas dažnai viršija hidrologinių modelių struktūros ar parametrų nulemtą neapibrèžtumą (Kay ir kt., 2009; Prudhomme, Davies, 2009a, b; Poulin ir kt., 2011; Kriaučiūnienè ir kt., 2013).

Mènesio laiko žingsnio vandens balanso modeliai taikyti ir tiriant klimato kaitos poveiki Lietuvos ir gretimu teritorijų hidrologijai (Kilkus ir kt., 2006; Stonevičius, 2008; Stonevičius ir kt., 2008; Rimkus ir kt., 2012). Daugumoje šių tyrimų akcentuojamas nuotèkio sezoninio pasiskirstymo pokytis, nulemtas klimato kaitos, tačiau kol kas detaliai neanalizuota, koks yra šių konceptualių mènesio laiko žingsnio modelių neapibrèžtumas, stiprybès ir silpnybès.

Šiame darbe siekiama ịvertinti, ar mènesio laiko žingsnio vandens balanso modeliai tinka vertinti regionui būdingų vidutinio dydžio upių su skirtingų savybių baseinais nuoteki, bei nustatyti, kurie modelio rezultatai yra labiau, o kurie mažiau patikimi. Klimato kaitos poveikio hidrologijai tyrimuose informacija apie modelio rezultatų patikimumą leidžia spręsti, ar numatomi pokyčiai yra nulemti klimato kaitos, ar pačio modelio struktūros. Ty- rimas atliktas pasitelkus vieną iš pasaulyje plačiai naudojamu ir klasikiniu laikomą ThornthwaiteMather (toliau - TM) (Thornthwaite, Mather, 1955) vandens balanso modeli. Kituose vandens balanso modeliuose laikomasi panašios struktūros, tad šio tyrimo rezultatus, atsižvelgus ị modelių struktūros skirtumus, galima pritaikyti vertinant ir kitų vandens balanso modelių rezultatų patikimumą.

\section{DUOMENYS IR DARBO METODIKA}

Vertinant modelio tinkamumą Lietuvos upių nuotèkio skaičiavimams pasirinktos penkios vidutinio dydžio Lietuvos upès: 1) Minija; 2) Jūra; 3) Šventoji; 4) Žeimena; 5) Merkys. Tirtos baseinų dalys, esančios aukščiau ilgas debitų sekas turinčių vandens matavimo stočių (VMS) (1 lentelè). Minija ir Jūra yra Vakarų Lietuvos upès, o Šventosios, Žeimenos ir Merkio baseinai išsidèstę Rytų Lietuvoje (1 pav.). Dèl skirtingo šių Lietuvos dalių klimato, žemènaudos ir dirvožemių skiriasi tiriamụjų upių maitinimas. Tiriamosiose vakarų upėse dominuoja maitinimas lietaus vandeniu (50-55 \% metinio nuotekio tūrio). Požeminio vandens dalis metų nuotèkyje sudaro tik apie 20-23\%. Likusi dalis - sniego tirpsmo vanduo (20-30\%). Šventosios nuotèkyje maitinimas lietaus ir sniego vandeniu sudaro apie $30 \%$, o maitinimas požeminiu vandeniu yra šiek tiek didesnis (40 \%) nei vakarų upèse. Žeimenoje ir Merkyje požeminio vandens dalis metiniame nuotèkyje dar didesnè (60-63 \%) (Kilkus, Stonevičius, 2011).

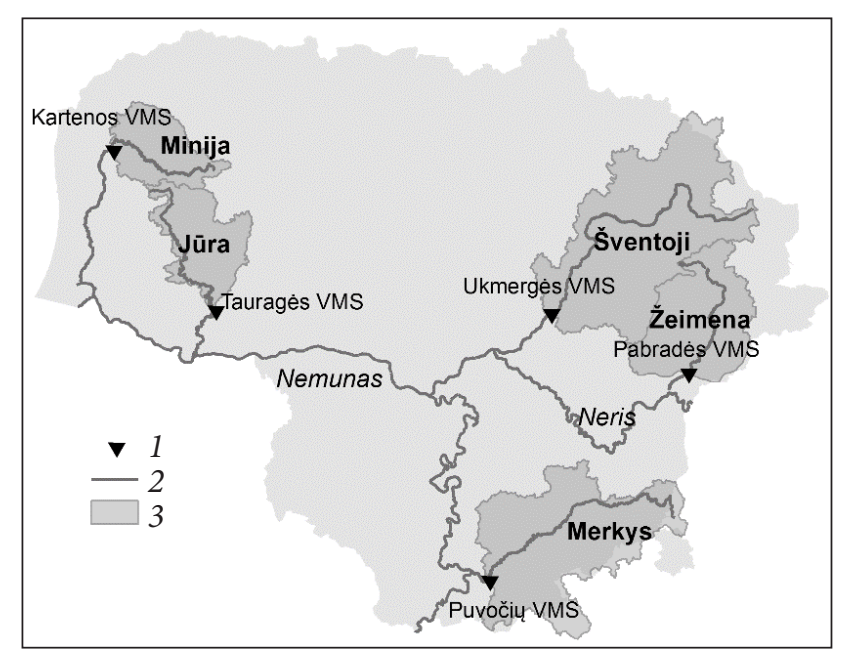

1 pav. Tiriamųjų upių baseinų pasiskirstymas (1 - vandens matavimo stotis, 2 - upès, 3 - tirtieji upių baseinai) Fig. 1. Distribution of analyzed catchments (1 - hydrological station, 2 - rivers, 3 - analyzed catchments) 
Baseino ir klimato savybès lemia, kaip upèmis nutekantis vanduo pasiskirstys per metus. Baseinuose su sunkesniais gruntais vyrauja paviršinis nuotèkis, todèl ì baseiną patekęs vanduo greičiau nuteka, baseine užsilaiko mažiau vandens, ir sausmečiu nuotẻkis būna mažesnis. Baseinuose su lengvesniais gruntais, didesniu ežeringumu ir miškingumu nuotèkis būna labiau sureguliuotas, tolygiau pasiskirstęs per metus (1 lentelè).
Šiame darbe taikyta TM modelio modifikacija pritaikyta Lietuvos sąlygomis (Stonevičius, 2009) (2 pav.), joje potenciali evapotranspiracija vertinama pagal C. W. Thornthwaite (1948) pasiūlytą metodą, o kritulių fazinè sudètis ir sniego dangos tirpsmo rodikliai apskaičiuojami iš menesio kritulių sumos ir vidutinès oro temperatūros duomenų, remiantis temperatūros indekso metodu (Okmura, 2001).

1 lentelè. Tirtųjų upių baseinų dydžiai ir nuotèkio sureguliavimo koeficientai (Kilkus, Stonevičius, 2011)

Table 1. Area and natural runoff regulation coefficients of analyzed catchments (Kilkus, Stonevičius, 2011)

\begin{tabular}{c|c|c|c}
\hline $\begin{array}{c}\text { Upè } \\
\text { River }\end{array}$ & $\begin{array}{c}\text { Žemutinis tirtojo baseino skerspjūvis } \\
\text { The lower cross-section } \\
\text { of the catchment }\end{array}$ & $\begin{array}{c}\text { Baseino plotas km } \\
\text { Catchment area, } \\
\boldsymbol{k m}^{\mathbf{2}}\end{array}$ & $\begin{array}{c}\text { Natūralaus nuotèkio } \\
\text { reguliavimo koeficientas } \boldsymbol{\varphi} \\
\text { Natural runoff regulation coefficient } \boldsymbol{\varphi}\end{array}$ \\
\hline Minija & Kartenos VMS & 1230 & 0,58 \\
\hline Jūra & Tauragès VMS & 1664 & 0,50 \\
\hline Šventoji & Ukmergès VMS & 5440 & 0,70 \\
\hline Žeimena & Pabradès VMS & 2580 & 0,82 \\
\hline Merkys & Puvočių VMS & 4300 & 0,85 \\
\hline
\end{tabular}

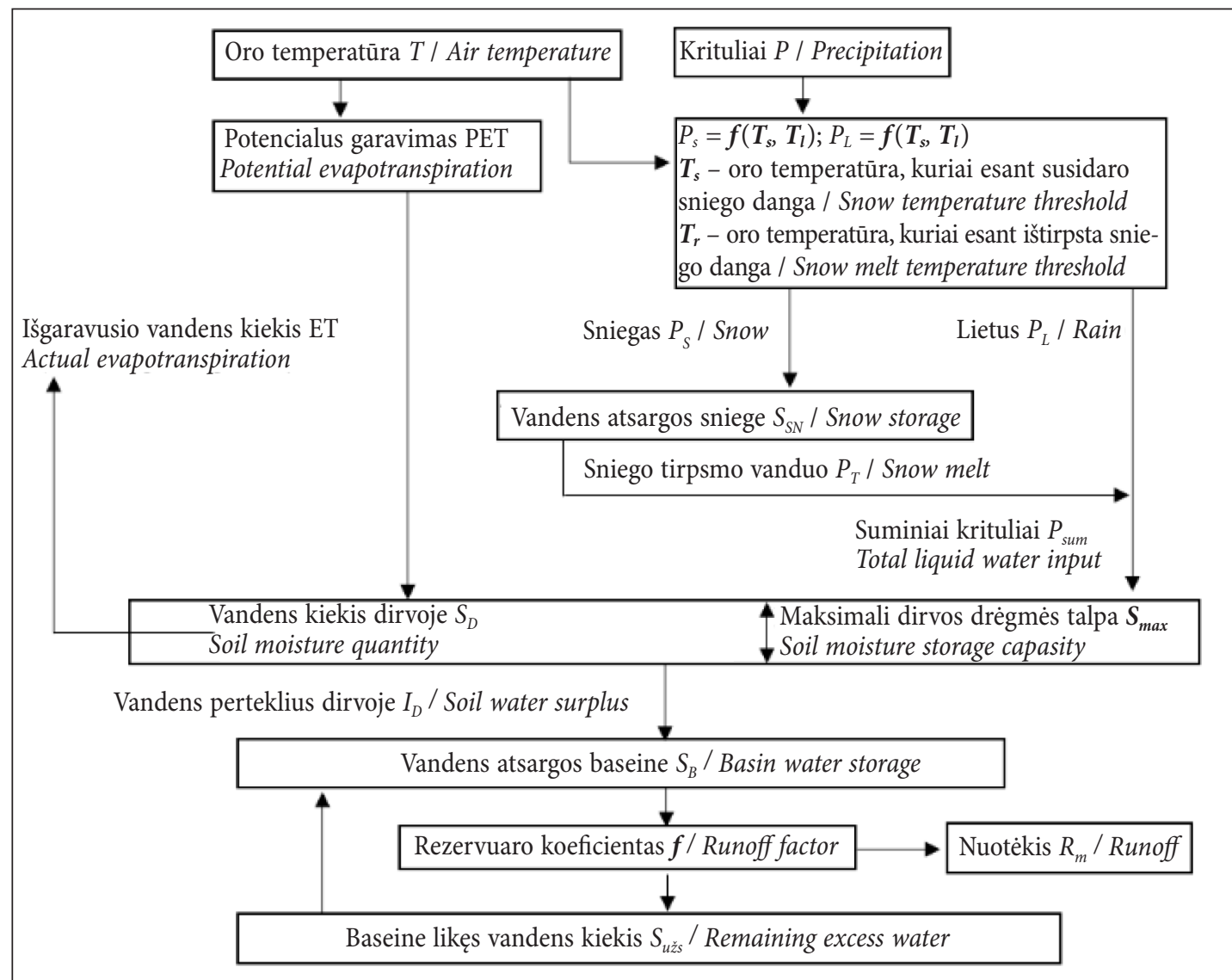

2 pav. Thornthwaite-Mather modelio su sniego moduliu konceptualioji diagrama (paryškintu šriftu pažymèti modelio parametrai)

Fig. 2. Conceptual diagram of Thornthwaite-Mather model with incorporated snow module (model parameters are noted in bold) 
Taikant matematinị modelị konkrečiam baseinui atliekamas modelio kalibravimas, kurio metu parenkami tokie modelio parametrai (lygčių koeficientai), su kuriais modelio reakcija $\mathfrak{i}$ išorès veiksnių poveikị yra panašiausia $\mathfrak{i}$ tiriamosios sistemos reakciją. Naudojamoje TM modelio modifikacijoje yra keturi kalibruojami parametrai: maksimali dirvos drègmès talpa $S_{\max }(\mathrm{mm})$, rezervuaro koeficientas $f$, oro temperatūros riba $T_{L}$ $\left({ }^{\circ} \mathrm{C}\right)$, aukščiau kurios iškritę krituliai yra lietus, ir oro temperatūros riba $T_{S}\left({ }^{\circ} \mathrm{C}\right)$, žemiau kurios visi iškritę krituliai yra sniegas. Maksimali dirvos drègmès talpa $S_{\max }$ naudojama skaičiuojant tikrąji garavimą. Vertinama, kiek įsotintas vandeniu yra dirvožemis konkretų ménesị ir kokia yra tą ménesi klimato sąlygu nulemta potenciali evapotranspiracija. Jei vandens atsargos dirvoje yra lygios maksimaliai dirvos drègmès talpai, tada garavimas iš baseino paviršiaus yra lygus potencialiai evapotranspiracijai. Rezervuaro koeficientas $f$ apibūdina, kokia dalis baseine sukauptų vandens atsargu nutekès. Pagal $T_{L}$ ir $T_{S}$ parametrus apskaičiuojama kritulių fazinè sudètis ir sniego dangoje sukauptos vandens atsargos.

TM modelio kalibravimas buvo atliktas naudojant Monte Karlo metodą (Metropolis, Ulam, 1949). Šis metodas paremtas didelio skaičiaus atsitiktinių modelio parametrų verčių derinių generavimu ir vertinimu, kurie iš šių sugeneruotų derinių yra optimaliausi taikant modeli konkrečiam baseinui. Generuojant parametrų derinius būtina apsibrèžti galimų parametrų verčių ribas. Parametrų, susijusių su agregatine kritulių bùsena ir sniego dangos rodikliais, ribos buvo pasirinktos atsižvelgiant i J. McCabe, S. L. Markstrom (2007) rekomenduojamas vertes $T_{L}[1,0$; $6,0], T_{S}[-8,0 ;-2,0]$. Sudarant parametrų derinius naudotos visos galimos rezervuaro koeficiento $f$ reikšmès $[0 ; 1]$. Apatinè rezervuaro koeficiento vertès riba $(f=0)$ atitinka situaciją, kai baseine sukauptas vanduo visiškai nenuteka, o nuotèki formuoja tik paviršinis nuotèkis. Viršutinè rezervuaro koeficiento vertès riba $(f=1)$ būtų pasiekiama tada, kai visos baseine sukauptos vandens atsargos galètu nutekèti upe per vieną mènesį. Paskutinio parametro maksimalios dirvos drègmès talpos $S_{\text {max }}$ žemutine riba pasirinkta $0 \mathrm{~mm}$, o viršutine $-500 \mathrm{~mm}$.

TM modelio tinkamumas atspindèti konkretaus baseino nuotekio formavimąsi vertintas pa- sitelkiant modelio tinkamumo rodiklius. Bendras TM modelio tinkamumas ivvertintas pagal NashSutcliffe modelio efektyvumo koeficientą $E$ (Nash, Sutcliffe, 1970). Vienas iš svarbiausių Nash-Sutcliffe koeficiento privalumų yra lengvai interpretuojamos jo reikšmès. $E$ koeficiento reikšmès kinta nuo $-\infty$ iki 1 . Jei modelio efektyvumo koeficientas $E$ mažesnis už nuli, tai stebejimų vidurkis yra informatyvesnis nei naudojamas modelis. Idealiai modelio rezultatai atitinka matavimo rezultatus tada, kai modelio efektyvumo koeficientas $\mathrm{E}=1$, tačiau laikoma, kad modelis pakankamai tiksliai imituoja tiriamąją sistemą, kai Nash-Sutcliffe koeficientas yra didesnis nei 0,5 .

Nash-Sutcliffe koeficientas tiksliai apibūdina bendrą modelio atitikimą, tačiau šiame darbe siekiama ívertinti, kokios yra TM modelio stipriosios ir silpnosios pusės ir kokius hidrologinio režimo rodiklius modelis apibūdina patikimiausiai. Dèl šios priežasties naudoti dar du papildomi tinkamumo rodikliai: vidutinè klaida $\Delta R$ ir koreliacijos koeficientas $r$. Vidutinè klaida $\Delta R$ parodo, kiek vidutiniškai per laiko žingsnị sumodeliuotas nuotèkis buvo didesnis ar mažesnis už išmatuotą nuotèki, tačiau neteikia informacijos apie nuotèkio sezoninès ar daugiametès kaitos atitikimą. Koreliacijos koeficientas $r$ naudotas nustatant modeliuoto ir išmatuoto nuotekio fazių sutapimą. Aukšta koreliacijos koeficiento verte rodo, kad TM modelis tiksliai atspindi potvyniu ir nuoslūgių laiką, tačiau sumodeliuoto nuotèkio dydis gali labai skirtis nuo išmatuoto.

Modelio įvesties duomenys - 1971-2000 m. mènesio kritulių kiekio suma ir vidutinè mènesio oro temperatūra, to pačio laikotarpio vidutiniai mènesio debitai, tirtųjų baseinų nuotèki geriausiai reprezentuojančiose vandens matavimo stotyse, imti iš Lietuvos hidrometeorologijos tarnybos archyvo. Kritulių ir temperatūros duomenys, reprezentuojantys konkretų baseiną, apskaičiuoti kaip geografiškai baseinui artimų stočių vidurkis.

\section{MODELIO JAUTRUMO TYRIMAS}

Prieš taikant modeli konkrečiai sistemai patogu išsiaiškinti, kaip skirtingi parametrai keičia modelio rezultatus, ir ịvertinti, kokių parametrų pokyčiams modelio rezultatai yra jautriausi. Žinant, kaip kintant parametro vertems keičiasi modelio rezultatai, galima geriau suvokti pačią modeliu imituojamos 
sistemos struktūrą bei tikslingai ieškoti optimalių, tiriamąą sistemą geriausiai atspindinčių modelio parametrų verčių.

Vertinant modelio rezultatų jautrumą parametrų pokyčiams buvo atliekamas nuotèkio skaičiavimas TM modeliu keičiant vieno parametro vertes, kitus parametrus prilyginus galimų šių parametrų reikšmių intervalo vidurkiui. Modelio rezultatų jautrumas parametrų pokyčiams labiausiai yra nulemtas pačios modelio struktūros, todèl poveikio kryptis visuose tiriamuosiuose baseinuose buvo vienoda, o skyrèsi tik poveikio dydis. Iliustruojant modelio parametrų poveiki apskaičiuotam nuotèkiui pateikti atlikti Jūros upès skaičiavimai (3 pav.).
Jautriausiai TM modeliu skaičiuojamas nuotèkis reaguoja ị rezervuaro koeficiento $f$ kaitą. Mažos $f$ koeficiento vertès lemia vandens užsilaikymą baseine, todèl metinè nuotèkio kaita yra labai maža (3a pav.). Didejjant rezervuaro koeficientui didesnè dalis vandens atsargų, sukauptų baseine, gali nutekèti per konkretų laiko žingsnį, todèl šio koeficiento kaita labiausiai veikia sezoninio nuotèkio amplitudę. Kai rezervuaro koeficientas pasiekia 1, vanduo baseine nesikaupia.

Maksimalios dirvos drégmès talpos $S_{\max }$ poveikis TM modeliu apskaičiuotam nuotèkiui labiausiai pasireiškia antroje metų pusèje (3b pav.). Maksimalios dirvos drégmés talpos parametras TM modelyje leidžia ịvertinti konkretaus ménesio

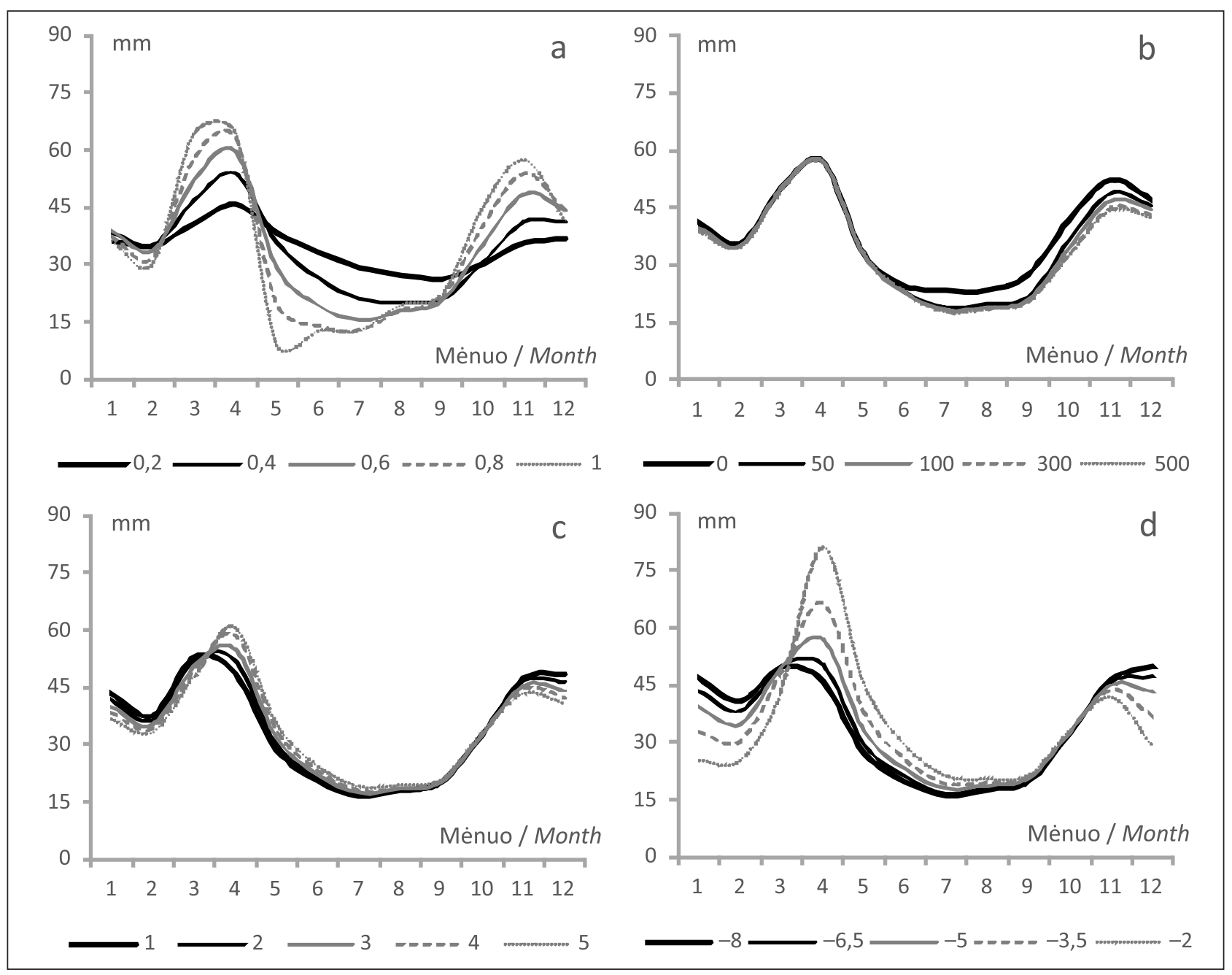

3 pav. TM modeliu apskaičiuoto Jūros upės nuotėkio $(\mathrm{mm})$ priklausomybẻ nuo parametrų verčių (a - rezervuaro koeficientas $(f)$; b - maksimali dirvos drègmès talpa $S_{\max }(\mathrm{mm}) ; \mathrm{c}$ - oro temperatūros riba $T_{L}\left({ }^{\circ} \mathrm{C}\right)$, aukščiau kurios iškritę krituliai yra lietus; $\mathrm{d}$ - oro temperatūros riba $T_{S}\left({ }^{\circ} \mathrm{C}\right)$, žemiau kurios visi iškritę krituliai yra sniegas)

Fig. 3. Jüra River runoff calculated with different parameter values (a - reservoir coefficient $(f)$; $b-$ maximum soil moisture content $S_{\max }(\mathrm{mm}) ; c$ - threshold temperature $T_{L}\left({ }^{\circ} \mathrm{C}\right)$ above which all precipitation is liquid; $d$ - threshold temperature $T_{S}\left({ }^{\circ} \mathrm{C}\right)$ below which all precipitation is snow) 
dirvos ísotinimą drègme ir lemia, kokia dalis potencialios evapotranspiracijos realizuosis $\mathfrak{i}$ išgaravusio vandens kiekį. Didinant $S_{\max }$ vertę, esant tam pačiam dirvos drègmès kiekiui, mažèja dirvos įsotinimas drègme ir garavimas, o apskaičiuotas nuotèkis turètų didèti. Be garavimo, maksimalios dirvos drégmès talpa TM modelyje naudojama apskaičiuoti dirvoje susidarantị vandens perteklių. Jei dirvos drègmè viršija maksimalią talpą TM modelyje, laikoma, kad susidaręs drègmès perteklius papildo baseino vandens atsargas, o didejant baseino vandens atsargoms dideja ir nuotèkis. Dèl šios priežasties didinant $S_{\max }$ vertę mažesnis kiekis vandens papildo baseino vandens atsargas, todèl modeliu apskaičiuotas nuotèkis turètų mažèti. Maksimalios dirvos drègmés talpos $S_{\max }$ poveikis vertinant dvi skirtingas nuotèkio formavimosi stadijas yra priešingas. Didinant $S_{\max }$ mažèja garavimas iš dirvos paviršiaus, tačiau dirva gali būti greičiau prisotinama drègme, todèl didèja baseino vandens atsargos. Ar didejant $S_{\max }$ TM modeliu apskaičiuotas nuotèkis didès, ar mažès, priklauso nuo ì tiriamąją sistemą iškrentančių kritulių ir potencialios evapotranspiracijos santykio. Lietuvos klimato sąlygomis didejant maksimaliai dirvos drégmès talpai $S_{\max }$ sumažeja nuotèkis nuo vasaros nuosèkio pradžios iki kitų metų pavasario potvynio pradžios (3b pav.).

Oro temperatūros riba $T_{L}$, aukščiau kurios iškritę krituliai yra lietus, ir oro temperatūros riba $T_{S}$, žemiau kurios visi iškritę krituliai yra sniegas, lemia, kiek iškritusių ị baseiną kritulių bus sniego pavidalo ir kaip intensyviai tirps sniego danga. Jei $T_{S}$ ir $T_{L}$ parametrų vertes padidinsime, tai TM modeliu skaičiuojant fazinę krituliu sudètị net ir esant sąlyginai aukštai temperatūrai (tačiau mažesnei nei $T_{L}$ ) galès formuotis sniegas, todèl apskaičiuotas metinis sezono sniego kiekis bei sniego dangoje sukauptos vandens atsargos bus didesnès. TM modeliu apskaičiuotas nuotékis jautresnis $T_{S}$ parametro kaitai nei $T_{L}(3 \mathrm{c}, \mathrm{d}$ pav.), nes jei vidutinè ménesio oro temperatūra yra mažesnè už $T_{S}$, tai visi per ménesį iškritę krituliai bus sniego pavidalo, o $T_{L}$ parametras lemia, kokią dalị iškritusių kritulių sudarys sniegas, jei vidutiné ménesio oro temperatūra yra tarp $T_{S}$ ir $T_{L}$.

Nuo $T_{S}$ ir $T_{L}$ parametrų labiausiai priklauso šaltojo sezono modeliu apskaičiuotas nuotèkis, tačiau sniego dangos formavimasis ir tirpsmas veikia baseino vandens atsargų sezonini pasiskirstymą, todèl sniego dangos rodikliams įvertinti naudojamų parametrų poveikis apskaičiuotam nuotèkiui stebimas ir kitais metu sezonais (3c, d pav.). Didinant $T_{S}$ ir $T_{L}$ baseine susikaupia daugiau sniego, todèl žiemos metu, kai iškritę krituliai kaupiasi sniego dangoje, nuotèkis sumažeja, o sniego tirpsmo metu nuotèkis labai padidejja. Sniego dangos susidarymą lemiantys parametrai veikia tik sezoninị nuotèkio pasiskirstymą, metinis nuotèkis nuo jų nepriklauso.

\section{MODELIO KALIBRAVIMAS}

TM modelio parametrai modelio rezultatus gali veikti priešingomis kryptimis (3 pav.), todèl skirtingi jų deriniai gali lemti toki pat rezultatą. Bandant modeli pritaikyti konkrečiam baseinui yra tikslinga išbandyti įvairius parametrų derinius ir ivertinti, kaip su šiais parametrų deriniais modelis geba imituoti procesus, vykstančius tiriamame baseine. Šiame darbe, ieškant kiekvieną upès baseiną geriausiai atspindinčių parametrų verčių, Monte Karlo metodu buvo sugeneruota 1000 derinių iš kiekvieno parametro galimų reikšmių intervalo. Vèliau su šiais parametrų deriniais skaičiuotas modelio ir matavimo rezultatų atitikimas. Modelio parametrų derinių tinkamumas ịvertinamas lyginant, kaip modelis geba atspindèti vidutinę daugiametę sezoninę nuotèkio kaitą.

Ieškant optimalių parametrų verčių pirmiausia yra tikslinga ịvertinti, kaip modelio rezultatų tikslumas priklauso nuo labiausiai jų kaitą lemiančių rezervuaro koeficiento $(f)$ ir sniego susidarymo ribinès temperatūros $\left(T_{S}\right)$ parametrų (3 pav.).

Bendrą modelio ir matavimų rezultatų atitikimą gerai atspindi Nash-Sutcliffe modelio efektyvumo koeficientas $E$. Remiantis $E$ koeficiento priklausomybe nuo rezervuaro koeficiento ir sniego susidarymo ribinès temperatūros, galima identifikuoti šių parametrų verčių intervalus, kuriuose TM modelio rezultatai yra geriausi (4 pav.). TM modelio rezultatai jautriausiai reaguoja $i$ rezervuaro koeficiento $f$ pokyčius, todèl geriausi modelio rezultatai vertinant visų tirtųjų upių nuotèki gauti naudojant sąlyginai siaurą $f$ parametro verčių intervalą. Mažu natūraliu reguliavimu pasižyminčiose Vakarų Lietuvos upèse (Minijoje ir Jūroje) geriausi modelio rezultatai gauti, kai naudotos rezervuaro koeficiento reikšmès 

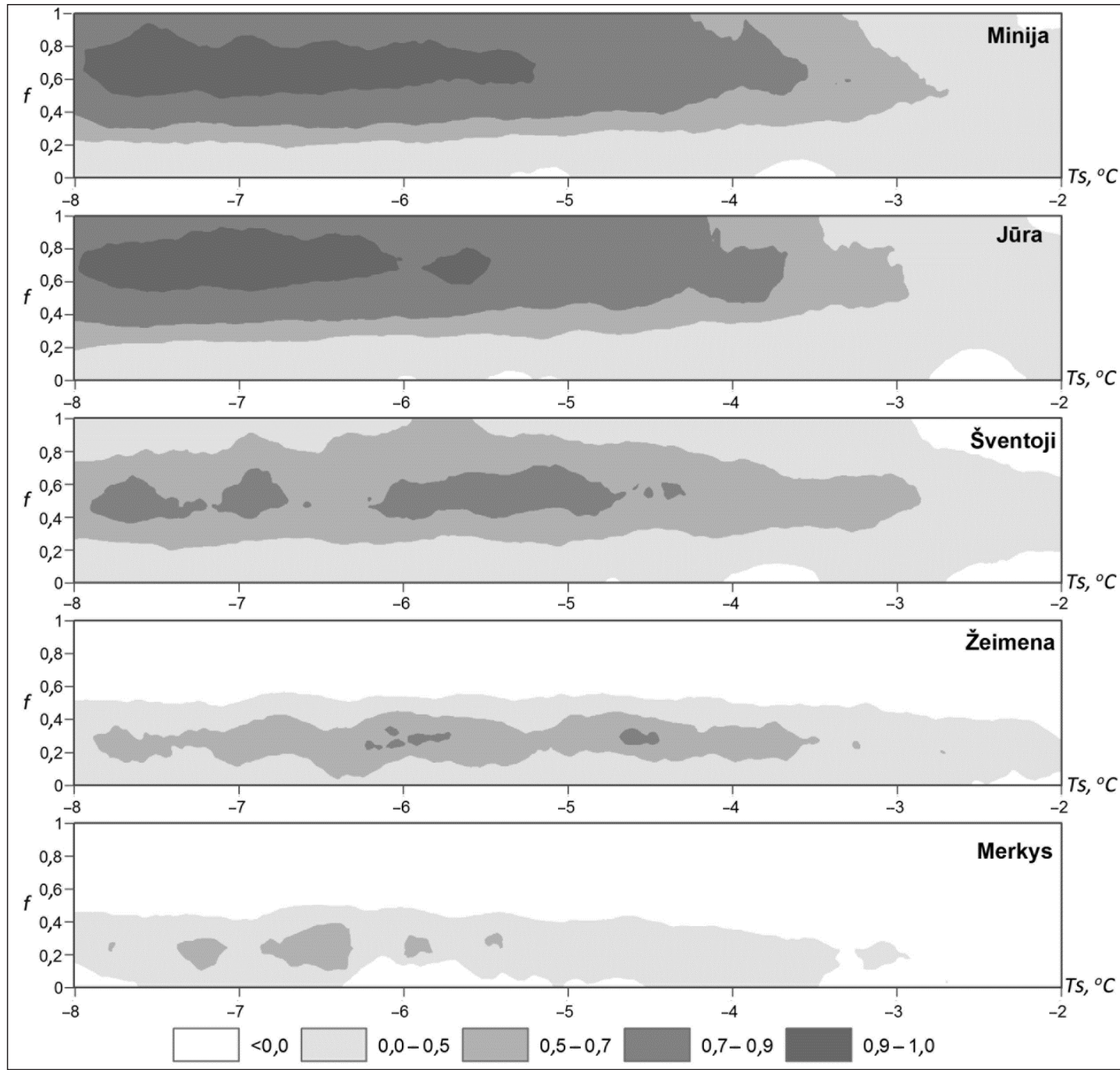

4 pav. Nash-Sutcliffe modelio efektyvumo koeficiento $E$ priklausomybė nuo skaičiavimams naudojamų rezervuaro koeficiento $(f)$ ir sniego susidarymo ribinès temperatūros $\left(T_{S}\right)$

Fig. 4. Nash-Sutcliffe model efficiency coefficient E dependence on reservoir coefficient $(f)$ and snow formation threshold temperature $\left(T_{S}\right)$

kito nuo 0,5 iki 0,9. Didejant upių baseinų natūraliam reguliavimui parametro $f$ reikšmès, su kuriomis gaunami geriausi modelio rezultatai, mažeja. TM modeliu apskaičiuotas Šventosios upès nuotèkis artimiausias išmatuotam tada, kai naudojamo rezervuaro koeficientas kinta nuo 0,3 iki 0,8 . Didžiausiu natūralaus reguliavimo koeficientu pasižyminčių Žeimenos ir Merkio upių nuoteki TM modelis geriausiai atspindi su mažesnèmis nei 0,5 rezervuaro koeficiento vertèmis. Sniego susidarymo ribiné temperatūra $\left(T_{S}\right)$ modelio rezultatų tinkamumą veikia mažiau, todèl geri modelio rezultatai gaunami gana plačiame šio parametro verčių intervale - nuo $-4 \mathrm{iki}-8^{\circ} \mathrm{C}$.

Nustačius parametrų $f$ ir $T_{S}$ sritis, kuriose modelio rezultatai geriausi, Monte Karlo metodu sugeneruoti nauji parametru deriniai naudojant identifikuotas parametrų sričių ribas. Iš šių parametrų derinių kiekvienai tirtajai upei atrinkta po 100 parametrų derinių, leidžiančių modeliu apskaičiuoti nuotèki, artimiausią matavimo rezultatams. Net ir šimte modelio parametrų derinių, su kuriais gaunami geriausi modelio rezultatai, pastebima labai ịvairių konkrečių parametrų verčių. 
Ypač platus mažiau modelio rezultatus veikiančių $T_{L}$ ir $S_{\text {max }}$ parametrų verčių intervalas. Pavyzdžiui, i 100 parametrų derinių, su kuriais TM modeliu apskaičiuotas nuotèkis labiausiai atitinka Šventosios upès nuotèki, patenka $S_{\max }$ vertès nuo $140 \mathrm{iki}$ $500 \mathrm{~mm}$.

Identifikuoti pačias optimaliausias TM modelio parametrų reikšmes vertinant konkretaus baseino nuotèki yra sudètinga, nes keičiant modelio parametrus jo efektyvumo koeficientas $E$ ir apskaičiuotas nuotèkis kinta labai mažai. Dèl šios priežasties vertinant, kaip TM modelis geba apskaičiuoti vidutinę daugiametę sezoninę nuotẻkio kaitą, buvo remtasi ne tik vienu optimaliu parametrų deriniu (2 lentelè), bet ir atsižvelgta $\mathfrak{i}$ neapibrèžtumą, atsirandantị identifikuojant optimalius parametrus. Neapibrèžtumo, kuris atsiranda nustatant parametrus, poveikis apskaičiuotam nuotékiui atskleistas naudojant 100 geriausių parametrų derinių. Ivertintas kiekvieno $\mathfrak{i}$ šiuos derinius patenkančio parametro vidurkis $\bar{x}$ ir standartinis nuokrypis $s_{x}$. Nuotèkio neapibrèžtumas, atsirandantis dèl parametrų neapibrèžtumo, vertinamas skaičiuojant nuotéki su $\bar{x} \pm 2 \cdot s_{x}$ parametrų vertèmis (5 pav.).

Parametrų verčiu neapibrèžtumas gali labai paveikti apskaičiuoto upių nuotèkio neapibrèžtumą. Net ir su geriausiais parametrų verčių deriniais apskaičiuotas ménesio nuotekis gali skirtis 20-25 mm. Didžiausias absoliutus neapibrèžtumo dydis yra pavasario potvynio laikotarpiu ir po jo einančioje nuotèkio slūgimo fazèje (5 pav.), tačiau lygindami neapibrežtumo dydi su pačia nuotékio verte gauname, kad didžiausia santykinè paklaida vertinant nuotèki gali būti apskaičiuojama vertinant gegužès-rugsèjo mèn. nuotè- kị. Upèse, su tolygiai per metus pasiskirsčiusiu nuotèkiu, santykinè paklaida didžiausia balandžio mén. Didelès parametrų neapibrèžtumo paklaidos rodo, kad norint tiksliai įvertinti nuotèki būtina surasti optimalias parametrų reikšmes. Jei tinkamumo rodikliai keičiant modelio parametrų vertes nebekinta, tikslinga atlikti TM modelio kalibravimą, remiantis modelio rezultatų jautrumo parametru kaitai analize (3 pav.) ir vizualiniu modeliu apskaičiuotos bei pagal matavimo duomenis ìvertintos vidutinès daugiametès nuotekio kaitos palyginimu (5 pav.).

Vertinant vidutinę daugiametę nuotèkio sezoninę kaitą TM su optimaliais parametrais modelio rezultatai gerai atitinka matavimų duomenis (2 lentelè). Visoms tirtosioms upems Nash-Sutcliffe modelio efektyvumo koeficientas $E$ yra aukštesnis arba lygus 0,85 . Koreliacijos koeficientas, atskleidžiantis, kaip tiksliai atspindimas nuotèkio fazių laikas, taip pat labai aukštas. Sumodeliuoto nuotèkio tūris labai nedaug skiriasi nuo išmatuoto. Didžiausias nuotèkio tūrio skirtumas tarp TM modelio ir matavimo duomenu apskaičiuotas Šventosios upèje. Modeliu apskaičiuotas Šventosios nuotèkis vidutiniškai $2,3 \mathrm{~mm} /$ mèn. didesnis, nei įvertintas pagal matavimų rezultatus (2 lentelè).

TM modeliu pakankamai tiksliai įvertinamas nuotèkis pavasario potvynio laikotarpiu, tačiau TM modeliu apskaičiuotas Minijos ir Jūros nuotekkis vasaros nuosèkio laikotarpiu bei Šventosios upès nuotèkis nuo birželio iki gruodžio yra didesnis, nei nustatytas pagal matavimo duomenis (5 pav.). Šio laikotarpio nuotèkis, apskaičiuotas TM modeliu, priklauso nuo maksimaliu dirvos drègmès atsargų $S_{\max }$ dydžio (3 pav.), tačiau net ir

2 lentelè. Optimalių TM modelio parametrų ir modelio tinkamumo rodiklių vertès, apskaičiuotos vertinant modelio gebèjimą atspindèti vidutinę daugiametę sezoninę nuotèkio kaitą

Table 2. Optimal TM model parameters for simulation of mean seasonal distribution of runoff and indicators of model fit

\begin{tabular}{|c|c|c|c|c|c|c|c|}
\hline \multirow{2}{*}{$\begin{array}{l}\text { Upè } \\
\text { River }\end{array}$} & \multicolumn{4}{|c|}{$\begin{array}{l}\text { Modelio parametrai } \\
\text { Model parameters }\end{array}$} & \multicolumn{3}{|c|}{$\begin{array}{l}\text { Modelio tinkamumo rodikliai } \\
\text { Indicators of model fit }\end{array}$} \\
\hline & $f$ & $T_{s},{ }^{\circ} \mathrm{C}$ & $T_{L},{ }^{\circ} \mathrm{C}$ & $S_{\max }, \mathrm{mm}$ & $r$ & $\Delta R, \mathrm{~mm} / \mathrm{mèn}$. & $E$ \\
\hline Minija & 0,72 & $-5,0$ & 1,7 & 500 & 0,98 & 0,7 & 0,96 \\
\hline Jūra & 0,72 & $-7,2$ & 4,4 & 350 & 0,99 & $-0,6$ & 0,96 \\
\hline Šventoji & 0,56 & $-7,0$ & 5,9 & 410 & 0,96 & 2,3 & 0,87 \\
\hline Žeimena & 0,29 & $-6,5$ & 6,2 & 410 & 0,96 & 0,8 & 0,90 \\
\hline Merkys & 0,25 & $-6,9$ & 2,8 & 460 & 0,93 & 0,4 & 0,85 \\
\hline
\end{tabular}




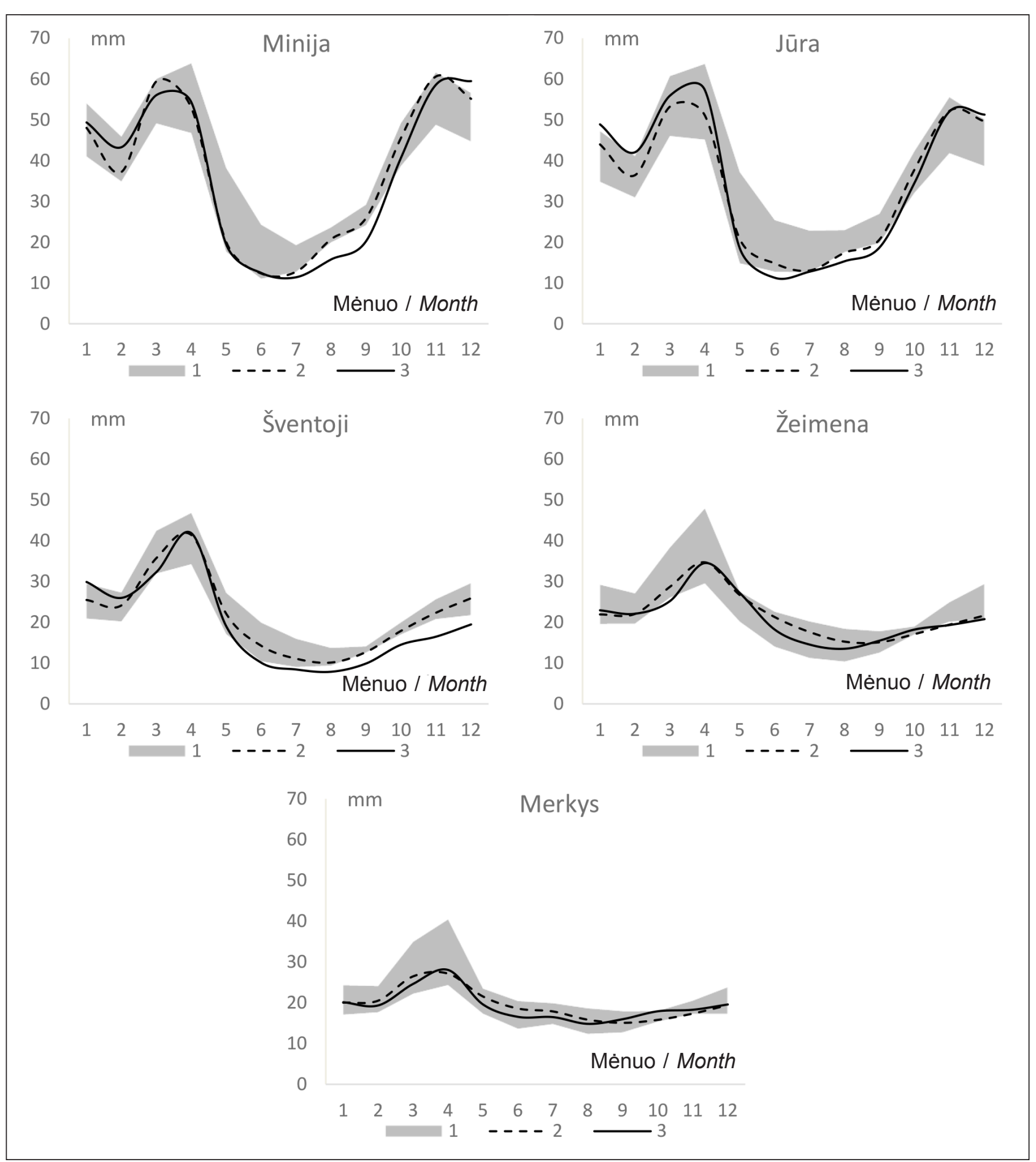

5 pav. Vidutinès daugiametės nuotẻkio sezoninės kaitos, apskaičiuotos TM modeliu, neapibrèžtumas (1), nuotẻkis nustatytas TM modeliu su optimaliomis parametrų reikšmėmis (2) ir ịvertintas pagal matavimų duomenis (3)

Fig. 5. Uncertainty of mean seasonal distribution of runoff calculated with TM model (1), runoff calculated with optimal parameter values (2) and calculated from measurement data (3)

labai padidinus šio parametro reikšmę apskaičiuotas nuotèkis išlieka didesnis nei išmatuotas.

Optimali rezervuaro koeficiento $f$ verte kiekviename iš tirtųjų baseinų gerai koreliuoja su natūralaus nuotèkio reguliavimo koeficientu $\varphi(r=0,98)$ (6 pav.). Apskaičiavus $\varphi$ koeficiento vertę iš turi- mų nuotèkio stebejjimų duomenų galima įvertinti tiriamajam baseinui tinkamą $f$ vertę. TM modeliu apskaičiuotas nuotèkis jautriausiai reaguoja $\mathfrak{i}$ rezervuaro koeficiento $f$ kaitą, tad žinant jo vertę labai palengvètų modelio pritaikymas pasirinktos upès baseinui. 


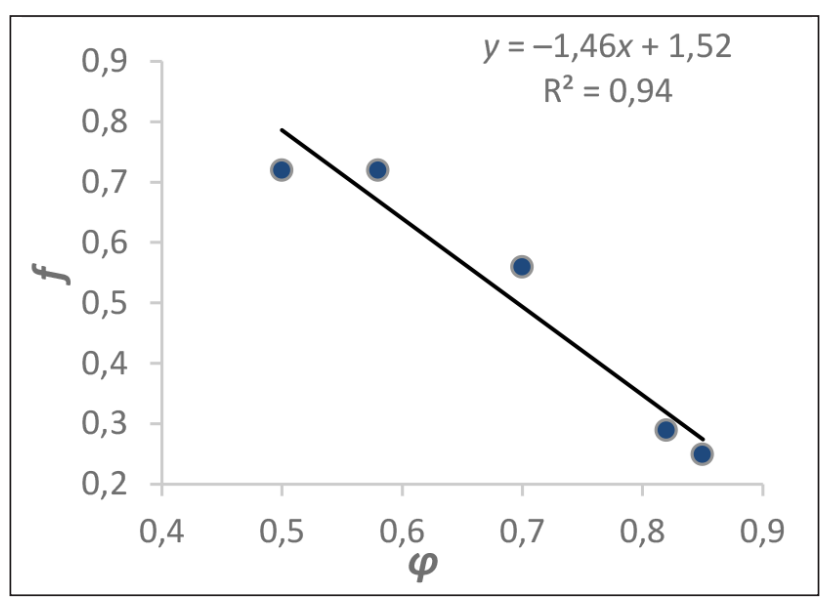

6 pav. Rezervuaro koeficiento $f$ priklausomybè nuo natūralaus nuotèkio reguliavimo koeficiento $\varphi$

Fig. 6. Regression between natural runoff regulation coefficient $\varphi$ and reservoir coefficient $f$

\section{MODELIO VALIDAVIMAS}

TM modelis sugeba gerai atkartoti vidutinę daugiametę tirtụjų upių nuotékio kaitą. Vertinant modelio tinkamumą remiantis vidutiniais duomenimis, teigiami ir neigiami nuokrypiai panaikina vieni kitus. Norint įsitikinti, ar modelis tinkamai atspindi procesus, vykstančius tiriamuose baseinuose, vertinta, kaip tiksliai apskaičiuojamas kiekvieno 1971-2000 m. ménesio nuotèkis (7 pav.). Visose tiriamosiose upèse TM modeliu apskaičiuoti didelių potvynių pikai ir minimalus nuotèkis vasaros nuosèkio laikotarpiu dažniausiai yra mažesni nei ivertinti pagal matavimo rezultatus. Modeliu ivvertintas ir apskaičiuotas iš stebejimų duomenų metinis nuotekis kai kuriais metais gali skirtis. Visose

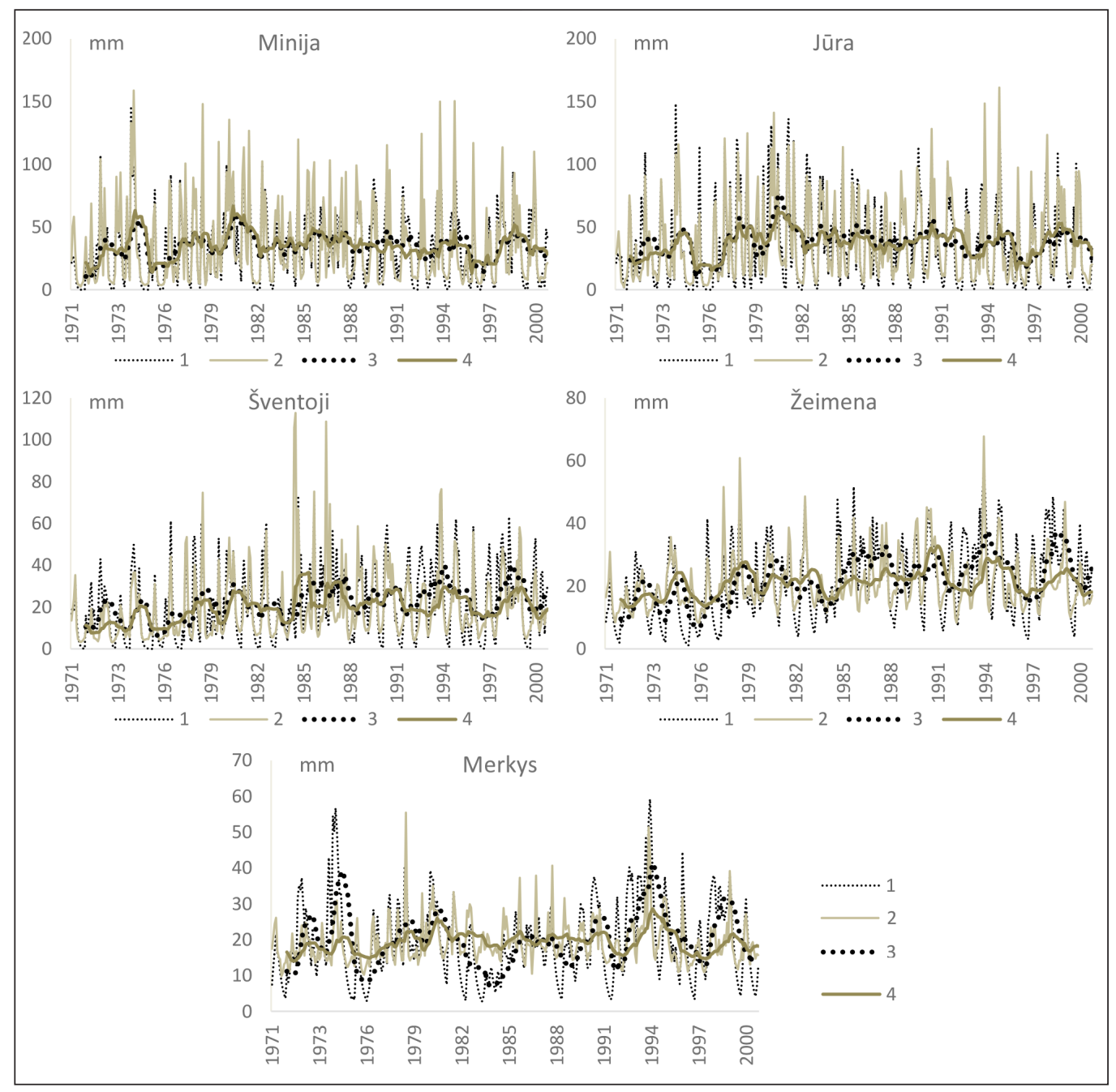

7 pav. TM modeliu apskaičiuoto (1) ir išmatuoto (2) vidutinio mėnesio nuotėkis 1971-2000 m. bei slankieji 12 mènesių modeliuoto (3) ir išmatuoto (4) nuotèkio vidurkiai

Fig. 7. Modeled with TM (1) and measured (2) monthly runoff in 1971-2000 and 12 month moving averages of modeled (3) and measured (4) runoff 
tiriamosiose upėse, išskyrus Miniją, modeliu apskaičiuotas nuotèkio tūris yra didesnis nei išmatuotas. Konkrečių metų nuotèkị TM modelis gerai ịvertina Minijoje ir Jūroje. Daugiau nei du trečdalius metų šiose upèse modeliu apskaičiuotas metinis nuotèkio tūris nuo išmatuoto skyrèsi mažiau nei $10 \%$. Šventosios upèje mažiau nei $10 \%$ skyrèsi tik 14 metų nuotèkis. Net 7 metus metinis nuotèkis apskaičiuotas modeliu buvo didesnis daugiau nei $30 \%$ už stebètą nuotèkį. Žeimenoje ir Merkyje metinio nuotèkio skirtumai pasiskirstę nuo 0 iki $50 \%$, tačiau mažesni nei $10 \%$ nuokrypiai pasitaiko tik 9 metus Žeimenoje ir 11 metų Merkyje.

Daugiamečius nuotèkio ciklus TM modelis gerai atspindi Minijoje ir Jūroje. Šių upių modeliu ir iš matavimų duomenų apskaičiuoto nuotèkio 12 ménesių slankieji vidurkiai beveik sutampa (7 pav.). Silpniau modelis įvertina Šventosios daugiamečius nuotèkio ciklus, o Žeimenoje ir Merkyje daugiamečiai nuotèkio ciklai TM modeliu atspindèti prastai.

3 lentelè. Nash-Sutcliffe modelio efektyvumo koeficientas $\mathrm{E}$, apskaičiuotas konkretiems metų mėnesiams. Pilka spalva pažymètuose langeliuose $\mathrm{E}$ neigiamas, didesnès už $0,5 \mathrm{E}$ koeficiento vertès pateiktos paryškintu šriftu

Table 3. Nash-Sutcliffe model efficiency coefficient calculated for a specific month of theyear. In gray cells $E$ is negative, values greater than 0.5 are presented in bold

\begin{tabular}{c|c|c|c|c|c}
\hline $\begin{array}{c}\text { Mènuo } \\
\text { Month }\end{array}$ & Minija & Jüra & Šventoji & Žeimena & Merkys \\
\hline 1 & $\mathbf{0 , 7 3}$ & $\mathbf{0 , 7 0}$ & $-0,19$ & $-0,05$ & $-0,96$ \\
\hline 2 & $\mathbf{0 , 8 2}$ & $\mathbf{0 , 5 9}$ & $-0,12$ & $-0,08$ & $-1,74$ \\
\hline 3 & $\mathbf{0 , 7 1}$ & $\mathbf{0 , 5 6}$ & $\mathbf{0 , 6 0}$ & 0,14 & 0,21 \\
\hline 4 & 0,39 & 0,41 & $\mathbf{0 , 5 4}$ & 0,35 & $-0,01$ \\
\hline 5 & $-0,01$ & $-0,02$ & $-0,09$ & 0,17 & $-3,91$ \\
\hline 6 & $-1,73$ & $-3,31$ & $-2,89$ & $-1,64$ & $-4,12$ \\
\hline 7 & $-2,04$ & $\mathbf{0 , 5 0}$ & $-3,64$ & $-8,12$ & $-4,42$ \\
\hline 8 & $-1,71$ & 0,22 & $-5,23$ & $-6,06$ & $-6,12$ \\
\hline 9 & 0,42 & $\mathbf{0 , 5 5}$ & $-4,84$ & $-3,18$ & $-4,24$ \\
\hline 10 & $\mathbf{0 , 7 6}$ & $\mathbf{0 , 7 6}$ & $-0,33$ & $-0,71$ & $-4,29$ \\
\hline 11 & $\mathbf{0 , 8 2}$ & $\mathbf{0 , 7 7}$ & $-0,73$ & $-0,66$ & $-4,50$ \\
\hline 12 & $\mathbf{0 , 7 1}$ & $\mathbf{0 , 5 7}$ & $-0,25$ & $-0,59$ & $-3,38$ \\
\hline
\end{tabular}

TM modelis tiksliai atspindi nuotèkio fazių kaitą Minijoje $(r=0,86)$ ir Jūroje $(r=0,88)$. Šventosios nuotékio kaitos fazès atspindimos blogiau $(r=0,75)$. Blogiausiai 1971-2000 m. ménesių nuotèkio kaitą TM modelis atspindi Žeimenoje $(r=0,61)$ ir Merkyje $(r=0,52)$. Vidutinei daugiametei sezoninei nuotèkio kaitai tiriamuose upès baseinuose pritaikytas TM modelis tik Minijoje $(E=0,6)$ ir Jūroje $(E=0,8)$ efektyviai atspindi 1971-2000 m. nuotèkio kaitą. Vertinant Šventosios nuotèki Nash-Sutcliffe modelio efektyvumo koeficientas $E$ lygus 0,3 , vadinasi, modelio efektyvumas yra mažas. Žeimenos ir Merkio daugiamečio nuotèkio kaitos TM modelis su parametrais, optimaliais vertinti sezoninę nuotèkio kaitą, neatspindi $(E<0)$. Bendras modelio efektyvumo koeficientas apskaičiuotas iš visų 1971-2000 m. duomenų neatspindi, kuriuo metų laiku jis yra efektyviausias. Kiekvienam metų mènesiui iš 30 metų duomenų apskaičiuotas Nash-Sutcliffe modelio efektyvumo koeficientas $E$ rodo, kad TM modelis sukalibruotas atspindèti sezonini nuotèkị efektyviai vertina $(E>0,5)$ daugiametę spalio-kovo laikotarpio nuotèkio kaitą Minijoje ir Jūroje (3 lentelè). Šventosios upeje modelis tinkamai apibūdina tik kovo ir balandžio mèn. daugiametę nuotèkio kaitą, o Žeimenoje ir Merkyje visais metų menesiais TM modelis blogai atspindi daugiametę nuotèkio kaitą. Daugumą ménesių Šventojoje, Žeimenoje ir Merkyje Nash-Sutcliffe modelio efektyvumo koeficientas $E$ neigiamas, todèl šiais mènesiais vidutinis nuotekis yra informatyvesnis nei TM modelis su pasirinktais parametrais.

\section{IŠVADOS}

Jautriausiai TM modeliu apskaičiuotas nuotèkis reaguoja i rezervuaro koeficiento $f$ ir ribinès sniego susidarymo temperatūros $T_{S}$ kaitą. İ likusių dviejų parametrų - maksimalios dirvos drègmès talpos $S_{\max }$ ir ribinès sniego tirpsmą nusakančios temperatūros $T_{L}$ - kaitą apskaičiuotas nuotèkis reaguoja mažiau, todèl taikant TM modeli konkrečiai upei svarbiausia tiksliai nustatyti optimalias $f$ ir $T_{S}$ parametrų vertes.

TM modeliu apskaičiuotą nuotèkị, veikiantị rezervuaro koeficientą $f$, galima ịvertinti pagal glaudų ryši $(r=0,98)$ su tiriamosios upès natūralaus nuotèkio reguliavimo koeficientu $\varphi$, kuris apskaičiuojamas iš ilgalaikių kasdienių upès debitų duomenų.

TM modelis su kiekvienam upès baseinui parinktu optimaliu parametrų deriniu gerai atspindi vidutinę daugiametę sezoninę nuotekkio kaitą, ypač 
tiksliai atspindima potvynio fazè. Vertinant visų tirtųjų upių nuotėkio sezoninị pasiskirstymą TM modelio efektyvumo koeficientas $E$ buvo didesnis nei 0,84 , o apskaičiuotas nuotèkis vidutiniškai skyrèsi mažiau nei $2,3 \mathrm{~mm}$ per mènesí.

$\mathrm{Su}$ vidutinę daugiametę sezoninę nuotèkio kaitą geriausiai apibūdinančiais TM modelio parametrais apskaičiuotas 1971-2000 m. konkrečių mènesių nuotèkis geriausiai atspindimas Jūros ir Minijos upèse. Modeliu apskaičiuotas šių upių metinis nuotèkis dažniausiai skiriasi nuo išmatuoto mažiau nei $10 \%$, o daugiametè nuotèkio kaita atspindima labai tiksliai. Modelio efektyvumas yra mažas vertinant Minijos ir Jūros nuoteki gegužèsspalio mèn. Šventosios nuotekị TM modelis su pasirinktais parametrais efektyviai atspindi $(E>0,5)$ tik gegužès ir balandžio mèn., o vertinant Žeimenos ir Merkio nuotèki TM modelio efektyvumas yra mažas $(E<0,5)$.

TM modelis gerai atspindi vidutinę daugiametę sezoninę kaitą visuose tiriamuosiuose baseinuose, tačiau konkrečių ménesių nuotèkis tiksliai ịvertintas tik upèse su mažai natūraliai sureguliuotu nuotèkiu.

Gauta 20160818

Priimta 20161010

\section{LITERATŪRA}

1. Arnall N. W. 1992. Factors controlling the effects of climate change on river flow regimes in a humid temperate environment. Journal of Hydrology. 132: 321-342.

2. Boorman D. B., Sefton C. E. M. 1997. Recognising the uncertainty in the quantification of the effects of climate change on hydrological response. Climate Change. 35: 415-434.

3. Gleick P. H. 1986. Methods for evaluating the regional hydrologic impacts of global climatic change. Journal of hydrology. 88: 97-116.

4. Gleick P. H. 1987. The development and testing of a water balance model for climate impact assessment: modeling the Sacramento Basin. Water Resources Research. 23: 1049-1061.

5. Jiang T., Chen Y. D., Xu C.-Y., Chen X. H., Chen X., Singh V. P. 2007. Comparison of hydrological impacts of climate change simulated by six hydrological models in the Dongjiang Basin, South China. Journal of Hydrology. 336: 316-333.

6. Kay A. L., Davies H. N., Bell V. A., Jones R. G. 2009. Comparison of uncertainty sources for climate change impacts: flood frequency in England. Climate Change. 92: 41-63.
7. Kilkus K., Štaras A., Rimkus E., Valiuškevičius G. 2006. Changes in water balance structure of Lithuanian rivers under different climate change scenarios. Aplinkos tyrimai, inžinerija ir vadyba. 2(36): 3-10.

8. Kilkus K., Stonevičius E. 2011. Lietuvos vandenu geografija. Vilnius: Vilniaus universitetas.

9. Kriauciuniene J., Jakimavicius D., Sarauskiene D., Kaliatka T. 2013. Estimation of uncertainty sources in the projections of Lithuanian river runoff. Stochastic Environmental Research and Risk Assessment. 27: 769-784.

10. McCabe G. J., Ayers M. 1989. Hydrologic effects of climate change in the Delaware River basin. Water Resources Bulletin. 25: 1231-1242.

11. McCabe G. J., Markstrom S. L. 2007. A Monthly Water-Balance Dodel Driven by a Graphical Interface. U.S Geological Survey Open-File Report. 2007-1088. 6 p.

12. Metropolis N., Ulam S. 1949. The Monte Carlo method. Journal of the American Statistical Association. 44(247): 335-341.

13. Najafi M. R., Moradkhani H., Jung I. W. 2011. Assessing the uncertainties of hydrologic model selection in climate change impact studies. Hydrological Processes. 25: 2814-2826.

14. Nash J. E., Sutcliffe J. V. 1970. River flow forecasting through conceptual models. Part I. A discussion of principles. Journal of Hydrology. 10(3): 282-290.

15. Ohmura A. 2001. Physical basis for the temperature-based melt index method. Journal of Applied Meteorology and Climatology. 40: 753-761.

16. Poulin A., Brissette F., Leconte R., Arsenault R., Malo J. S. 2011. Uncertainty of hydrological modelling in climate change impact studies in a Canadian, snow dominated river basin. Journal of Hydrology. 409 (3-4): 626-636.

17. Prudhomme C., Davies H. 2009a. Assessing uncertainties in climate change impact analyses on the river flow regimes in the UK. Part 1: baseline climate. Climate Change. 93: 177-195.

18. Prudhomme C., Davies H. 2009b. Assessing uncertainties in climate change impact analyses on the river flow regimes in the UK. Part 2: future climate. Climate Change. 93: 197-222.

19. Rimkus E., Korneev V., Pakhomau A., Stonevičius E. 2012. Climate Change in the Nemunas River Basin: Observed Trends and Future Predictions. UNECE projekto ataskaita. https://www2.unece.org.

20. Stonevičius E., Štaras A., Valiuškevičius G. 2008. Dirvožemio drègmès režimo pokyčiu XXI a. prognozès pagal skirtingus klimato kaitos scenarijus. Geografija. 44(1): 17-25.

21. Stonevičius E. 2008. Klimato kaitos poveikio nestratifikuoto ežero vandens balansui ir eutrofikacijai tyrimas (Žuvinto ežero pavyzdžiu): daktaro disertacija. Vilniaus universitetas. 
22. Stonevičius E. 2009. Thornthwaite-Mather vandens balanso modelio optimizavimas Monte Karlo metodu. Geografija. 45(1): 54-61.

23. Thornthwaite C. W. 1948. An approach toward a rational classification of climate. Geographical Review. 38(1): 55-94.

24. Thornthwaite C. W., Mather J. R. 1955. The water balance. Publication in Climatology. 8(1): 1-104.

25. Wang W., Shao Q., Yang T., Peng S., Xing W., Sun F., Luo Y. 2013. Quantitative assessment of the impact of climate variability and human activities on runoff changes: a case study in four catchments of the Haihe River basin, China. Hydrological Processes. 27: 1158-1174.

26. Xu C. Y., Singh V. P. 1998. Review on monthly water balance models for water resources investigations. Water Resources Management. 12: 31-50.

\section{Edvinas Stonevičius, Dovydas Reitelaitis}

\section{APPLICATION OF THORNTHWAITE-MATHER WATER BALANCE MODEL TO LITHUANIAN RIVERS}

\section{Summary}

The monthly water balance models are usually applied to catchments where the availability of meteorological and hydrological data is limited or there is not enough information to describe the catchment in more advanced models. In this study the Thornthwaite-Mather water balance model is applied to five medium-sized Lithuanian rivers with different water supply composition and runoff seasonality. The main scope of the study is to evaluate the model ability to represent the runoff formation in catchments with different properties and to identify the strengths and weaknesses of the monthly water balance model.

The model sensitivity analysis was performed to identify the parameters who mostly affect the calculated runoff. The Monte Carlo optimization was used to determine the optimal Thornthwaite-Mather parameters set for each analyzed catchment. The mean seasonal runoff distribution is well represented by the model with the optimal parameters. The model results best fit the measured runoff during winter and spring flood. While the representation of the summer and autumn runoff formation is not as accurate. The multiannual runoff dynamics is better represented by the model in rivers with large runoff seasonality and where rain water substantially contributes to the total runoff. In such rivers the model is sufficiently effective to simulate the October-April runoff. The model with the selected parameter values is not capable to represent the multiannual runoff dynamics in rivers with low runoff seasonality due to the model ineffectiveness during the most months of the year.

Keywords: runoff, modeling, Thornthwaite-Mather model, sensitivity analysis, Monte Carlo optimization 